\title{
Women Empowerment and Good Urban Governance in Iran
}

\author{
Razieh Rezazadeh \\ Department of Architecture and Urban Design \\ Iran University of Science and Technology, Narmak, Tehran, Iran \\ E-mail: rezazadeh@iust.ac.ir
}

\begin{abstract}
The purpose of this paper is to examine the role of women in urban management and possibility of a more inclusionary approach to their active participation. First the underlying concepts and principles of Good Urban Governance and special needs of women in urban settings are discussed; next capabilities of Iranian women for active participation in Good Urban Governance are examined.
\end{abstract}

The study shows that women are in utter need to be empowered and to take more active role in their urban lives. Furthermore, it shows that Iranian women have used the means available to them to improve their capabilities. It discusses that there are needs for further research to better understand the socio-cultural obstacles to higher participation rate of women in governance.

The paper is an original investigation of Iranian women's attempt to improve their lives through the available means to them within a paternalistic society. It discusses their success and failures and draws future directions of their latent movement.

Keywords: Urban governance, Empowerment, Women, Iran

Traditionally municipalities were in charge of managing urban development and providing daily services. It is proposed that due to their authoritarian nature and lack of participation, their practice usually neglects the needs of various marginalized groups including women. It is discussed that Good Urban Governance overcomes this deficiency. Governance is concerned about the process of governing communities at all levels. Governance is best defined by United Nations Development Agency (UNDP) as:

"The exercise of economic, political and administrative authority to manage a country's affairs at all levels. It comprises the mechanisms, processes and institutions, through which citizens and groups articulate their interests, exercise their legal rights, meet their obligations and mediate their differences" (UNDP 1977, p. 1).

Good Urban Governance is mainly defined through its characteristics and it is a participatory and inclusionary approach which calls for engagement of all groups, including women in the decision making process. Based on principles of Good Urban Governance, this paper discusses the need for inclusion of women in the decision making process of cities in Iran. Basically women activists in Iran argue for more gender sensitive urban management. The secular groups discuss attaining women's right through a gender equality approach while religious groups argue for gender justice (Murozzi, 2009).

This paper reviews women's role in everyday urban life and emphasizes not only women's personal needs and requirements, but also their requirements to enable them to best perform their role as caregivers. It notes women's concerns for urban environments, their recent achievements in terms of progress in education and employment in Iran, and discusses obstacles to more active participation in urban governance through representation in city councils and/or other participatory means. It preserves women's ability to perform this role through their newly attained qualifications and within the value system of a transforming society. This article discusses that Iranian women have had good progress in self-empowerment through education and to some extent employment; also they have strived for political and legal rights. It concludes that, the next step would be participation in urban governance.

\section{Good Urban Governance}

Good Governance is a concept that has come into use in political science, public administration and, more particularly, urban development, planning and management in recent years. It appears alongside such terms as democracy, civil society, participation, human rights and sustainable development and promotes these concepts. It has been closely associated with the public sector reform during the past decade. 
Good Governance has eight major characteristics. It is participatory, consensus oriented, accountable, transparent, responsive, effective and efficient, equitable and inclusive and finally follows the rule of law (UNESCAP, 2007). It is believed that Good Governance not only assures that corruption is minimized, but also that the views of minorities are taken into account and that the voices of the most vulnerable in society are heard in the decision-making process.

As opposed to the autocratic traditional urban management systems, Good Urban Governance through a democratic process calls for the participation of all residents regardless of gender, ethnicity and other personal characteristics in the decision making process. Enhancing the role of women in urban governance is a pre-condition for Good Urban Governance. Therefore, a policy on women and urban governance should address two aspects;

1) Greater attention to issues of concern to women to foster gender-awareness and competence among both women and men in the political arena and planning practice,

2) Increasing women's participation and representation in local decision-making.

Participation and civic engagement are critical determinants of Good Governance, a concept that addresses issues of social equity and political legitimacy. Participation needs to be informed and organized. Although women are key players at the local level in household livelihood strategies and domestic management, they are usually excluded from critical decision-making processes. Inclusive partnerships in urban governance need to take account of the obstacles to women's involvement in public life, such as a lack of skills, resources and the burden of multiple responsibilities. UNESCAP (2007) emphasizes on the conditions and procedures of Good Governance as follows:

There are diverse viewpoints about various issues within a given society. Good Governance needs to be consensus oriented in order to effectively mediate between the different interests in society. It must also take into account, the interests of the most vulnerable and underrepresented members of the society including women.

Transparency in decision-making is important for Good Governance. To achieve this, the rules and regulations for enforcement of decisions need to be transparent. Transparency would benefit most, the marginalized groups including women especially in traditional societies.

In paternalistic cultural environments, which women's public presence and acquisition of information is much harder than their male counterparts, direct access to information becomes especially important for women. Such direct access to information makes the system more responsive to the needs of all groups.

Effectiveness and efficiency in Good Governance means that processes and institutions produce results that meet the needs of society while making the best use of resources. For effectiveness and efficiency of plans and programs, consideration of the needs of various groups including women is important.

The aim of the principle of equity and inclusiveness in Good Governance is to enforce the feeling that all members of society have stakes in the society and are part of it, creating a sense of belongingness. This requires all groups, particularly the most vulnerable and marginalized ones including women and amongst them the deprived and the poor, to have opportunities to improve their lives.

Equity is a prerequisite for any action aimed at improving people's quality of life. Gender equity is not only a question of fundamental human rights and social justice, but it is also instrumental and a precondition for environmental sustainability and human development.

Good Governance requires the rule of law which needs fair legal frameworks that are enforced impartially. It also requires full protection of human rights, particularly those of the minorities and the marginalized including women.

\section{Urban Management in Iran}

In Iran, municipalities administered daily services since ancient times, but this in its modern form began close to a century ago. However, as Madanipour (2006) reports on the case of Tehran, urban management and municipal bodies were always governed through domination of central government. Furthermore, preparation of urban plans to guide urban development was a centralized procedure in which the Ministry of Housing and Urban Development was responsible for its preparation. The model adapted was the same as the comprehensive urban planning model used in Europe and North America. This model has been criticized for many issues including its centralized nature and lack of participation. One such critical note is as follows; "the urban plan mechanism in Iran has been from the top down.....public opinion is ignored because there is no distinct mechanism for including public participation in the preparation or implementation of plans" (Farhoodi, R.; Gharakhlou, M.; 
Ghadami, M.; \& Panahandeh Khah M. 2009, p.343).

The traditional municipality system was authoritarian in which the mayor was not selected through democratic voting system, but rather was appointed by government as its representative at local level. Madanipour (1999) accounting for Tehran municipality states that, "The absence of democratic governance makes it difficult, if not impossible, for the citizens to play an active part in management of the city" (Madanipour, 1999, p.64). While today participation is recognized as a key element in Good Urban Governance, the established system was short of any democratic element until the enactment of city councils and later neighborhood councils. In fact, the 1979 constitution of the Islamic Republic required establishment of local councils in urban and rural areas, however, this was not realized until 1997.

The system is now modified and citizens, through city councils, have the opportunity to enter the decision-making process for their city. They can vote for their nominees and take part in urban management in an indirect and passive participatory manner. Furthermore, they can nominate themselves in city councils for direct and active involvement in the decision making process. Although, this allows for new opportunities, there are still problems, partially hindering women from active participation in the governance process. Therefore, the way women have benefited from this new opportunity must be examined. A brief review of recent developments would shed light on this issue.

\subsection{Necessity of Women's Inclusion}

Gender is a social construct concerning the social relations between men and women. In our urban life there are gender inequalities reflecting access to power and to the decision-making processes. This concern is not only about access to power, but also access to urban services and amenities.

As Secor (2004) quotes Henri Lefebvre (1996), "the right to the city" refers not only to the rights to urban services such as housing, work, and education, it also refers to the right to participate in making "the urban," the right to inhabit and transform urban space and thus to become a creator of the city. However, gender inequalities inhibit the right to the city for the "second class citizens".

On the other hand the concerns of men and women regarding their inhabiting environments are different. A comparative research in Asia, Africa and East Europe shows that "women do not respond to urban problems in the same manner as men do. They are more inventive in community management; they work constantly to maintain social cohesion, and housing and the quality of life in neighborhoods remain an obsession" (Hainard \& Verschuur, 2003, p. 478). In addition, they have particular concerns and needs which must be considered. Through participation women would have the chance to express themselves, be heard and achieve decision making powers to effect their living environment.

\section{Issues of Concern for Women}

Women and men experience and use the urban environment in different ways and often have different priorities in terms of urban services and infrastructure. United Nations Center for Human Settlements has developed a special set of gender sensitive normative goals to promote Good Urban Governance at local decision-making levels. These are decentralization and participatory democracy, equity, efficiency, and security (UNCHS, 2000a).

Enhancing the role of women in urban governance is a pre-condition for the inclusive city promoted by the -Global Campaign for Good Urban Governance-. UNCHS (2000b) has also recognized the following areas for strategic attention as issues of concern to women which Good Urban Governance needs to consider. These include issues of basic services, human rights, economic capacity, transport, violence and security of tenure.

\subsection{Basic Services}

Women are more dependent on basic services. They deal with water, sanitation, fuel and waste management due to their domestic responsibilities. Lack of basic services and infrastructure affects women directly. Their viewpoints are very important in urban planning and management process. Informing women of the scarcity of resources and their inclusion in decision making and planning process makes them socially and culturally more responsive towards appropriate use of basic services.

\subsection{Transport}

While there are similarities among the transportation needs of men and women, especially in terms of commuting to and from work or school/university, there are areas where the needs of men and women are different. Women have gender-specific needs around their homes. As mothers and care givers, women have to accompany others. Many women are working in informal economy sector, with a flexible work schedule. Yet traditional urban transportation planning often disregards some of the concerns of women and is basically 
preoccupied with journeys of the formal sector workers. Moreover, women are more likely to travel in off-peak periods with less frequent public transport services. While many women are solely dependent on public transportation, conditions of travel on public transport are often very unpleasant. Safety is a major concern for women using public transport. These gender-sensitive issues must be considered in Good Urban Governance.

\subsection{Economic capacity}

Since home base work is a very common employment pattern among women, the economic capacity of women in urban areas is linked to both the basic services and the security of tenure. Provision of appropriate services is very important in facilitating and providing economic capacity for women. In addition, appropriate mixed-use zoning which provides daily needed land uses including daycare facilities within neighborhoods is a gender-sensitive approach which strengthens the economic capacity of women.

\subsection{Security of Tenure}

Considering the increasing percentage of female headed households around the world, security of tenure becomes an important issue. Female headed households who usually suffer unemployment and lack of economic resources are economically and physically marginalized and pushed into older and dilapidated areas of cities. Many of these areas are subject to local renovation projects without considering the special issues of women. Therefore, many families including female headed households are subjected to displacement causing disruption of social ties and loss of existing home based economic opportunities.

\section{Empowerment of Women}

Empowerment is a strategy to help the disadvantaged and the marginalized to gain power to change the quality of their lives. This requires active participation in decision making process. Women are one of the target groups for such an empowerment strategy as a means to realization of Good Urban Governance, which "strives to eradicate all forms of exclusion" (UNCHS, 2000a, p. 198). This would also enable carrying out an inclusionary and participatory planning approach. Their contribution can change the urban management through reduced corruption (Barry, Honour \& Palnitkar, 1998). Women are more concerned with environmental issues, sustainability, education, quality of neighborhoods, and basic services.

In the process of empowerment, women have experimented various ways to gain control of their lives. In a comprehensive study, Hainard \& Verschuur distinguish three different strategies so that woman can gain power in three different parts of the world. It seems that the Iranian case is best fit with the strategy of "appropriating power in a subtle manner .... without setting themselves explicitly and openly against the social norms in force, which are obviously favorable to men. This is "the strategy of non-competition with the menfolk, of non-contestation of customs" (Hainard \& Verschuur, 2003, p. 481).

Several international agencies have developed various gender-sensitive measures. Among these are Gender Development Index (GDI), and Gender Empowerment Measure (GEM) developed by United Nations Development Program (UNDP). While Human Development Index (HDI), measures the overall human development in a country, the gender development index compares women's and men's development based on discrepancy between life expectancy, educational attainment and income (CIDA, 1997). Gender empowerment index is to measure inequality in decision making process and is measured based on three factors of economic participation and decision making power; political decision-making and power; and power over economic resources. (Pillarisetti \& McGillivray, 1998)

These indices which are devised to measure development and empowerment are good measures to understand the capacity of women in Iran. They emphasize on the importance of education, economic activity and political participation as major issues which in turn enable realization of Good Urban Governance. Here, an overview of the capacity of women for participation in Good Urban Governance is conducted through a review of these indices.

According to 2009 Human Development Report of United Nations, Iran ranked 88 for its HDI and 76 for its GDI among 155 countries. The same report introduced a new index to measure the discrepancy between HDI and GDI of countries. The HDI ranks used in this calculation were recalculated for the countries with a GDI value. A positive figure indicates that the GDI rank is higher than the HDI; a negative figure, the opposite. The same report shows a discrepancy between its HDI and GDI for Iran at -2 which means that HDI is higher than GDI in Iran.

It is interesting to note that in the same report higher discrepancies exists both in the region and worldwide. In the region -5 goes to Oman and Pakistan, -6 for United Arab Emirates and Kuwait, -7 for Saudi Arabia and -8 for Jordan and Syria. The same report shows a discrepancy of -5 for Luxembourg, -6 for United States, and -9 for Australia. This shows that the Gender differences in Human development in Iran are not very bad comparing to the countries in the region and in some cases worldwide. 
Gender empowerment measure (GEM) shows that Iran is 103 among 109 countries, one of the lowest in the world. Countries with lower GEM than Iran are Morocco Algeria, Saudi Arabia, Egypt, Bangladesh and Yemen respectively. Table 1 shows that all these countries except Saudi Arabia have much lower HDI and GDI indices than Iran. This shows that Iran despite its medium rank in HDI and GDI and relative acceptable differences between these indices, is suffering from a very low GEM. The first two indices do notincorporate political involvement and participation of women in the decision making process while these are an important determining factor for GEM, and being responsible for lower GEM in Iran. Looking at detailed data would show some of the reasons behind this.

\section{Women's Capacity in Iranian Case}

There are some pre-requisite for women's participation in urban governance which are also important ways of empowerment; these include education, economic activity, and social activity. In this article these indices are studied for Iranian women in recent history.

Amir-Ebrahimi (2003) points that after the revolution, the imposition of hejab (Islamic dress code) in the traditional neighborhoods had not worsened the situation of women but it facilitated their access to new public spaces and to services such as educational facilities and professional jobs. Therefore, it actually had very important positive implications in their lives. Since then, Iranian women have transformed their lives in many aspects. The key social indicators of women's lives such as literacy, education level, and employment have improved greatly since the revolution. A study into some of these aspects gives a better insight into Iranian society and the position of women in Iran.

\subsection{Education and Literacy}

Literacy is a fundamental and influential prerequisite for women's participation in urban governance. Developing a core of empowered women to feed into decision-making bodies at city level is a key to implementing a policy of women participation in urban governance. Therefore, improving literacy is one of the first steps to improve participation of women in decision making processes.

According to the data obtained from Iranian National Census, two years before the Islamic Revolution in 1977, the literacy rate of women was only $35.5 \%$, while men's literacy rate was almost 59\%; a literacy gap of 23.4 existed. Since then the literacy rates for both men and women increased. This was due to the government's programs for literacy of adults including policies on literacy requirement for employment and recruitment of the work force. In 2007 national census, over 80 percent of women and almost 89 percent of men were literate, with a literacy gap of only 8.6. In addition, literacy was higher for urbanite population and for younger age groups. It must be noticed that not only the overall literacy rates have increased, but also the gender gap in terms of literacy has decreased (Statistical Center of Iran). Table 2 shows the national literacy rates for both male and female, as well as the literacy gap base on the Iranian National Census data for various dates.

This dramatic improvement is not only in literacy rates, but also in education levels as well. According to the same data, after the Islamic revolution, the rate of female students entering universities has increased rapidly; and since 2001 women constitute the majority of students entering higher education in Iran. In 2008, the ratio of female students grew to comprise 63 percent of the students entering university undergraduate programs throughout Iran. Entrance of women into masters and $\mathrm{PhD}$ programs is still lower than men.

\subsection{Employment}

Based on 2007 census, 61.6 percent of men and a mere 9.8 percent of women are economically active. Compared to the pre-revolutionary period, the official data do not show a significant increase in women's share in the labor force. However, these data indicate that the participants have much higher education and skills and are involved in a wide range of professional, managerial, and entrepreneurial activities. While the participation rate of women in the economically active population is very low, the economic participation rate of women with university qualifications is exceptionally high (78 percent). However, since many of the lower educated women are employed in informal economic sector, and are either self-employed, or working as unpaid family laborers, the rate of employment for women is underestimated.

In terms of types of jobs available to women, it must be noted that while women comprise almost one-third of government employees, they hold less than $7 \%$ of the administrative positions available (Statistical center of Iran, 2007). Considering the education level of the employees and the managerial positions available at that rank, the chances of a woman getting a managerial position is one third of that of a man's. Achievement of higher administrative positions would make governance positions culturally acceptable for the voters. 


\subsection{Representation}

During the first term of local council elections in 1999, there were 336,138 candidates for about 33,000 local councils (Majlis Research Center, 2010). According to the same data, women only comprised 2.2 percent of all the candidates. The total selected women councilors were only 1,375 throughout Iran comprising only 0.8 percent of the total councilors. The highest ratio of women councilors was in the city of Tehran at 3 percent, while in many city councils around Iran, there were not any women elected. The situation improved for the second term of elections in 2003 and the entry level for women into local councils rose from 0.8 to 1.4 percent of the total seats and stayed the same for the third term in 2007. Obviously, there is a large gap (97\%) between men and women councilors, which keeps the position a masculine one.

Faezeh Hashemi, daughter of former Iranian President, Ali Akbar Hashemi (1989-1997) and an influential women's right activist, supported female candidates of all factions throughout 1999 local elections. Mrs. Hashemi admired the courage of these women who had volunteered themselves to take part in socio-political activities as she puts it "in a male dominated society" (Povey, 2001). It must be noted that women are politically active and are well participating to cast ballots in elections. However, since they do not see themselves effective within the male dominated system, they do not aim for these positions.

Examining the social acceptance of women as councilors would clarify some of the socio-cultural obstacles. Table 3 shows the number of female and male candidates and elected councilors for the local councils since its establishment in 1999. In addition, it shows the ratio of female to all councilors in each term, as well as the chances of candidates to win the election for each term. It shows that chances of male candidates to win the election are between two to three times higher than that of female candidates.

Involvement of women in decision making at higher levels is an indicator of the rate of social acceptance of such roles for women. Recent history is very important to understand the context of the issue of social acceptance. The ratio of parliament seats in Iran during the Pahlavi era, which had claimed for freedom and rights of women, only rose to 7 percent for the national assembly and 5 percent for the Senate. Table 4 shows the number of women councilors in various terms during the pre-revolution era.

During the first three national elections after the Islamic revolution of 1979, only the female candidates from Tehran were elected for the Islamic Parliament. Even in later elections, half of the female candidates elected were from Tehran province. Table 5 shows the number of male and female councilors and the ratio of women in the parliament for all eight terms after the revolution. After a rise in 1996, there was a decline in the number of women taking over parliament seats. In 2010, the total number of women representatives is 8 out of 290 total seats, comprising only 3 percent of the total seats. Although women are not banned from taking part in political activities, their active participation rate, as candidates and councilors is negligible.

\section{Conclusion}

As Povey explains, "women in Iran have shown a great deal of courage, imagination and commitment to struggle for their gender interests" (Povey, 2001, p.69). Iranian women have proved their aim to change their lives and to transform the society in a more active way than before. Their first steps of capacity building and empowerment through education and employment were taken; It seems that there are further steps ahead including getting into higher professional and administrative jobs, and into the decision making process, including urban governance.

Inclusion of more women both as representatives as well as managers in the planning process is a good measure to assess the practice of Good Urban Governance (UNCCA, 2003). It is also in accordance with the UN recommendations for Iran, stating promotion of "gender equity and empowerment of women".

This can be achieved through introduction of a quota system examined in other countries as well as in Iran. In recent past, a quota system has been applied in Iran for both inclusion of university students from deprived regions of Iran as well as balancing out the number of female students at universities. This has very important effects in terms of human development indices. Same experience can help develop a culture of participation of women in governance.

Iranian activist women have more fundamental concerns about grass-root institutions and are involved with serious basic issues such as polygamy, the right to divorce and the custody of children. Therefore, at present they have put less effort into involvement in urban governance.

However, more fundamental changes beyond the gender issue are needed for realization of Good Urban Governance. These changes include a more participatory and inclusionary governance system; one which fully acknowledges and exercises the city council system and equal rights of all citizens, and advocates participation of marginalized groups including women. 


\section{References}

Amir-Ebrahimi, M. (2006). Conquering enclosed public spaces. Cities, 23, 455-461.

Barry, J., Honour, T., \& Palnitkar, S. (1998). Women, urban governance and the public service ethos. Crime, Law \& Social Change, 2, pp. 251-272, 1998.

CIDA. (1997). Canadian International Development Agency, Guide to Gender-Sensitive Indicators.

Farhoodi, R., Gharakhlou, M., Ghadami, M., \& Panahandeh Khah M. (2009). A critique of the prevailing comprehensive urban planning paradigm in Iran: the need for strategic Planning. Planning Theory, 8(4), $335-361$.

Hainard, F., \& Verschuur C. (2003). Gender relations and grass-roots urban movements. International Social Science Journal, 55, 473-488

Human Development Report. (2007/2008, 2009). [Online] Available: hdrstats.undp.org/en/indicators/125.html (Nov 7, 2010).

Madanipour, A. (1999). City profile - Tehran. Cities, 16, 57-65.

Madanipour, A. (2006). Urban planning and development in Tehran. Cities, 23, 433-438.

Majlis Research Center. (2010). Islamic Republic of Iran Parliament Research Center. [Online] Available: www.majlis.ir/mhtml/index.php (Nov 7, 2010).

Murozzi, N. C. (2009). Quiet Leadership and Pressure from Below: Women's Participation in Iranian Public Life, in: Middle East Program, Occasional Paper Series. 10-14.

Pillarisetti, J. R., \& McGillivray, M. (1998). Human development and gender empowerment. Development Policy Review, 16, 197-203.

Povey, E. R. (2001). Feminist contestations of institutional domains in Iran. Feminist Review, 69, 44-72.

Secor, A. (2004). There is an Istanbul that belongs to me. Annals of the Association of American Geographers, 94, 352-368.

Statistical Centre of Iran. (2007). Management and Planning Organization, Islamic Republic of Iran. [Online] Available: amar.sci.org.ir/ (Nov 7, 2010).

UNCCA. (2003). United Nations Common Country Assessment for the Islamic Republic of Iran. [Online] Available: www.undp.org.ir/DocCenter/reports/npd/CCA.pdf (Nov 7, 2010).

UNCHS (Habitat). (2000a). The global campaign for Good Urban Governance. Environment \&Urbanization, 12(1), 197-202.

UNCHS (Habitat). (2000b). Policy paper on women and urban governance. [Online] Available: www.gdrc.org/u-gov/gender/womgov.doc (Nov 7, 2010).

UNDP. (1997). Governance and Sustainable Development, New York, 2-3.

UNESCAP. (2007). United Nations Economic and Social Commission for Asia and the Pacific, What is Good Governance? [Online] Available: www.unescap.org/p (Nov 7, 2010). 
Table 1. Comparison of Iran with other Countries through Major Human Development and Gender Sensitive Indices

\begin{tabular}{|l|l|l|l|l|}
\hline & $\begin{array}{l}\text { GEM }^{1} \\
(2007 / 2008)\end{array}$ & $\begin{array}{l}\text { GDI }^{2} \\
(2009)\end{array}$ & $\begin{array}{l}\mathrm{HDI}^{3} \\
(2009)\end{array}$ & $\begin{array}{l}\text { GDI- HDI } \\
\text { Difference }\end{array}$ \\
\hline Iran & 103 & 76 & 88 & -2 \\
\hline Oman & 87 & 56 & 56 & -5 \\
\hline Pakistan & 99 & 124 & 141 & -5 \\
\hline United States & 18 & 19 & 13 & -6 \\
\hline UAE & 25 & 38 & 35 & -6 \\
\hline Kuwait & N/A & 34 & 31 & -6 \\
\hline Saudi Arabia & 106 & 60 & 59 & -7 \\
\hline Jordan & N/A & 87 & 96 & -8 \\
\hline Syria & N/A & 98 & 107 & -8 \\
\hline Austria & 20 & 23 & 14 & -9 \\
\hline
\end{tabular}

Source: Human Development Report (2007/2008, 2009)

${ }^{1}$ Gender Empowerment Measure

${ }^{2}$ Gender Development Index

${ }^{3}$ Human Development Index

${ }^{4}$ The HDI ranks used in this calculation were recalculated for the countries with a GDI value

Table 2. The Percentage of Literacy as well as the Literacy Gap

\begin{tabular}{|l|l|l|l|}
\hline Year & Male & Female & Literacy Gap \\
\hline 1977 & 58.9 & 35.5 & 23.4 \\
\hline 1987 & 71.0 & 52.1 & 18.9 \\
\hline 1992 & 80.6 & 67.1 & 13.6 \\
\hline 1997 & 84.5 & 74.7 & 9.8 \\
\hline 2002 & 86.1 & 77.0 & 9.1 \\
\hline 2007 & 88.9 & 80.3 & 8.6 \\
\hline
\end{tabular}

Source: Statistical Center of Iran

Table 3. The Number of Men and Women Candidates and Elected councilors for the Local councils

\begin{tabular}{|l|l|l|l|l|l|l|l|}
\hline Year & Female & Chance & Male & Chance & Female & Male & $\begin{array}{l}\text { Female } \\
\text { ratio }\end{array}$ \\
\hline 1999 & 7276 & 18.9 & 328862 & 49.4 & 1375 & 162605 & 0.8 \\
\hline 2003 & 5867 & 38.1 & 213090 & 71.8 & 2236 & 152983 & 1.4 \\
\hline 2007 & 7106 & 21.0 & N/A & N/A & 1491 & 107645 & 1.4 \\
\hline
\end{tabular}

Source: Majlis Research Center, (2010) 
Table 4. Relative Distribution of Women elected in the National Parliament

Source: Majlis Research Center, (2010)

\begin{tabular}{|l|l|l|l|l|}
\hline Term & 1963 & 1967 & 1971 & 1975 \\
\hline Number & 6 & 7 & 18 & 20 \\
\hline Percent & 3 & 3.3 & 6 & 7.5 \\
\hline
\end{tabular}

Table 5. The Number of Men and Women Taking over Parliament Seats after the 1977 Islamic Revolution

\begin{tabular}{|l|l|l|l|}
\hline Year & Female & Male & Female ratio \\
\hline 1980 & 4 & 95 & 4.0 \\
\hline 1984 & 4 & 118 & 3.3 \\
\hline 1988 & 4 & 176 & 2.2 \\
\hline 1992 & 9 & 133 & 6.3 \\
\hline 1996 & 14 & 131 & 9.7 \\
\hline 2000 & 12 & 262 & 4.4 \\
\hline 2004 & 13 & 270 & 4.6 \\
\hline 2008 & 8 & 277 & 2.8 \\
\hline
\end{tabular}

Source: Majlis Research Center, (2010) 